\title{
Exploring EFL Learners' Perceptions of Integrated Skills Approach: A Grounded Theory
}

\author{
Maryam Tajzad $^{1} \&$ Seyyed Ali Ostovar-Namaghi ${ }^{2}$ \\ ${ }^{1}$ Islamic Azad University, Shahrood Branch, Iran \\ ${ }^{2}$ Shahrood University of Technology, Iran \\ Correspondence: Seyyed Ali Ostovar-Namaghi, Department of Applied Linguistics, Shahrood University of \\ Technology, Iran. E-mail: saostovarnamaghi@yahoo.com
}

\author{
Received: August 11, 2014 Accepted: October 12, 2014 Online Published: October 23, 2014 \\ doi:10.5539/elt.v7n11p92 URL: http://dx.doi.org/10.5539/elt.v7n11p92
}

\begin{abstract}
This qualitative study aims at exploring EFL learners' perceptions of the integrated skills approach to language teaching. To this end, the researchers presented the integrated skills approach to a group of 30 participants and interviewed those who were willing to share their views and experience with the researchers. The researchers used grounded theory to collect and analyze interview data. Iterative data collection and analysis continued until theoretical saturation was reached. To establish credibility, transient and final categories were verified through member-checking. The results clearly show that the participants positively perceive this approach. The findings have implications for all stakeholders including policy makers, syllabus designers, practitioners and learners.
\end{abstract}

Keywords: grounded theory, integrated skills approach, learners' perceptions

\section{Introduction}

Although the Audio-lingual method waned in popularity, its main legacy, i.e., the skills and component model of language teaching still prevails in many EFL contexts including the private and public schools of Iran. Being immersed in this tradition, practitioners have forgotten the fact that an engine is a combination of several discrete elements, however, a car will never move unless these discrete elements are integrated in a systematic way into a unified whole. Along the same lines, students may learn language skills and components, but they will never be able to use them to communicate unless they can use language skills in an integrated fashion.

The problem is that Iranian EFL learners have an acceptable knowledge of language components such as grammar, vocabulary and the like, but they can rarely use them to communicate in English. The reason is that class time is devoted to learning grammar, vocabulary and the isolated reading skill, and rarely do they find the chance to use language skills in an integrated fashion. This process is analogous to the absurd task of giving someone cheese, butter, and cream and making him produce milk. To be effective, the process should be reversed.

To help communicatively incompetent learners, practitioners should present skills and components in an integrated fashion from the first day on. This study aims to involve EFL learners in reading information-rich texts and then ask them to use the information they received through reading for speaking and writing and compare the efficiency of this approach with the that of the traditional model.

\section{Review of Related Literature}

Proponents of the Audio-lingual method believed that language is basically aural-oral. Given such an emphasis, it appeared reasonable to separate language skills. Although the Audio-lingual learners knew isolated skills, they were not able to communicate their thoughts in English and they were not communicatively competent. In practic, it is rare for language skills to be used in isolation; e.g., both speaking and listening comprehension are needed in a conversation and, in some contexts, reading or listening and making notes is likely to be almost as common as having a conversation. Thus, all skills should be integrated.

Taking learners' communicative incompetence into account, there was a shift away from skills and component model towards the communicative approach. The central innovative characteristic of the communicative approach in second or foreign language teaching was the integration of the four macro-skills and their 
components, which can complement each other (Hinkel, 2010). To study a language, you may need to break the language into parts. To use it, however, the skills and components must be integrated.

As early as the 1970s, many researchers and methodologists noted that the teaching of language skills cannot be conducted through isolable and discrete structural elements since skills are not divorced from each other (Corder, 1971, 1978; Kaplan, 1970; Stern, 1992). Widdowson (1978) was one of the first linguists to call for integrating the four language skills in instruction to raise learners' proficiency levels and enable advanced language learning. "We can talk of skills in respect to usage, but if we talk about language use, we need a different concept, and perhaps a different term" (Widdowson, 1998, p. 325). Similarly, Canale's and Swain's (1980) clarified that practicing a range of language skills simultaneously and in the context of communication allow learners to reach levels of grammatical competence similar to those achieved by students who concentrated on Audio-lingual structural patterns.

In the 1980s and 1990s, a great deal of elaboration and refinement took place in communicative and integrated teaching of the four skills. These had to be interaction-centered and as authentic as possible to enable students to use the language for purposeful communication (Savignon, 1983, 1990). Having been accepted as a more efficient way of presenting language skills, skill integration has been variedly defined by different scholars.

Some have focused on integrating language and other school subjects. For instance, Joglekar, Bhuiyan, and Kishore (1994), defined integrated teaching as organization of teaching matter to interrelate or unify subjects frequently taught in separate academic courses or departments. Integration aims at giving the students a holistic instead of a segmented outlook on language learning process. Others have focused on integrating component parts of a discipline. Roberts and Kellough (2000), fore example, defined integration in the teaching and learning as a way of planning and organizing the instructional program for interrelating the discrete disciplines of subject matter in an appropriate design that brings about effective learning.

Post method researchers such as Oxford (2001) claimed that integrated language teaching is supposed to be an effective strategy for language learning as a whole. According to her, plenty of threads such as vocabulary, syntax, pronunciation, spelling, and meaning should be woven well to create the integrated approach. "If the strands are not woven together effectively and well, the instructional loom is likely to produce something small, weak, ragged, and pale--not recognizable as a tapestry at all" (Oxford 2001).

Despite our history of treating the four skills in separate segments of a curriculum, there is a recent trend toward skill integration which clarifies the advantages of this approach in EFL classrooms (Brown 2001). Among other advantages, research findings show that skill integration:

- Helps learners carry over their skills and declarative knowledge from one skill to another which facilitates and simplifies the improvement of the other skills (Strang, 1972).

- Creates a dynamic and exciting classroom environment (Richard-Amato, 1996).

- Enables learners to have a more realistic access to authentic language learning, whereas a segregated approach does not offer a meaningful understanding of language or a motivating style to learning a foreign language (Myers \& Hilliard, 1997).

- Leads to focus on realistic language and can therefore lead to the students' all-round development of communicative competence in English (Jing, 2006).

- Was enthusiastically accepted by students and most of them had a positive attitude toward this approach (Mitrofanova \& Chemezov, 2011)

- $\quad$ Leads to better comprehension of the material by students (Mitrofanova \& Chemezov, 2011).

Having taken the advantages of the integrated skills approach (ISA) into account, the researchers believe that this approach can alleviate the problem of communicative incompetence among EFL learners in private language schools of Iran. Thus the study aims at presenting EFL learners with the ISA, and exploring their perceptions of this approach. More specifically, it aims at evaluating the efficacy of this approach by answering the general question, "How do you perceive the integrated skills approach?

\section{Research Method}

\subsection{Why Grounded Theory}

Essentially, grounded theory has its origins in symbolic interactionsim, a paradigm which holds that individuals engage in a world that requires reflexive interaction as averse to environmental response. Consequently, grounded theory is suitable to the study of any behavior that has an interactional element to it. More specifically, 
it is an important method for studying topics of a social nature. "It is an inductive theory that allows the researcher to develop a theoretical account of the general features of a topic and simultaneously grounding the account in empirical observations or data" (Martin \& Turner, 1986, p. 141). This research method aims at developing a theory that is grounded in the words and actions of those individuals under study.

\subsection{Data Collection and Analysis}

This study aimed at conceptualizing EFL learners' perceptions of the ISA. Thus the researchers presented the this approach to a group of 30 participants and interviewed those who were willing to share their views concerning this approach. This information was then analysed through the application of open coding techniques, or line-by-line analysis, which helped to identify provisional explanatory concepts. In axial coding, the researchers tried to elaborate the concepts and categories by specifying their dimensions and properties and then fining the interrelationships between concepts and categories. At last, in selective coding the researchers found the core category, i.e., learners' perceptions of the integrated approach.

This super category pulled together all other categories that presented an explanatory theory which was grounded in learners words, actions and thoughts. Credibility of the findings was established through: (1) constant comparison, i.e., the provisional concepts and categories were constantly compared with transcripts in order to ensure consistency; and (2) member checking, i.e., provisional categories as well as the final conceptualization were shown to the participants and modifications were made for the best fit. According to the original rules of grounded theory, the researchers did not leave the field and stop sampling until theoretical saturation was reached.

\section{Results}

\subsection{Simultaneous Use of Skills}

Presenting skills in a segregated fashion may help learners to learn their knowledge of language but it will not enable them to use their knowledge in actual communication. On the other hand, integrating skills is a matter of language use. While the former approach is contrived in nature, the latter is a simulation of communication in actual contexts of use. Thus integrating the four main language skills, i.e., listening, reading, speaking, and writing, is very beneficial in the second language classroom. Considering that communication requires the integration of both the main and the accessorial skills, i.e., grammar, punctuation, pronunciation, it makes sense that language is taught in a communication promoting way, one of the participants explains:

From my point of view the integrated approach provided the conditions that all of us had the opportunity to practice language skills simultaneously and improve them uniformly. For example, while we were reading a text, we acquired some new knowledge and interesting ideas to claim in speaking or writing. I strongly want to express that this method let us share our knowledge in a calm and relaxed situation and also with a full and ready mind to write our writing task. I was personally really satisfied with this method since at the end of the term I had a remarkable change in my speaking and writing skills.

Another interviewee believed that this method was beneficial since it enabled them to meliorate the four main skills simultaneously and how they complement each other. They emphasized that the integrated approach is very helpful in the second language environment. In elaborating this point he states:

We quickly obtain a true understanding and using the language for communication in this method. We learned how to use English and communicate well and in a meaningful way. Since all of the four main skills were taught simultaneously to us, improving all skills, each one affected the other. For example, by reading texts I acquired some points and ideas for speaking and writing. Also, we could learn new words and grammatical points to use in our writing and speaking and thereby pay more attention and concentrate on reading while the teacher read it This in turn reinforced the listening skill.

\subsection{Increase in Learner's Motivation and Self-Confidence}

In integrated approach, language is treated as a means of interaction and interplay, rather than an academic subject. The ISA enables learners to interact properly and achieve to high level of motivation to learn a language. This also relates to motivation, and it is more likely for students to be motivated to learn a language if they are able to use it to interact, rather than to just have knowledge about the language. This point is clarified in students' interviews which show their satisfaction with interaction opportunities with other learners and teachers. These chances motivate them to express their own ideas and speak without any fear or stress. Learners find the class interesting. This is in drastic contrast with the traditional approach which is very boring for them. Confirming this, one of the participants explains: 
In this method, I wanted to speak most of the time because after reading the text we had a lot to talk about, I always had something to say. This really motivated me to talk while lacking information or knowledge decreases our motivation or may destroy it. This method was not teacher-centered and we were not passive listeners in the language class.

Participants' comments obviously show that they were very pleased with this method since most of them focused on gaining a high level of motivation and confidence to express themselves in speaking as well as writing. Another participant explains:

Since prior to interacting with each other we read these texts, we were motivated to participate in classroom discussion and attend classroom dialogues and collaborate with other learners, and ask and answer questions. I learned to speak somehow fluently at my level and I think I am motivated to speak for a longer period of time.

Integrating language skill paves the way for real communication in the classroom since it increases students' knowledge and gives them something to talk about. Confident speakers are those who have a high level of knowledge on the subject. Another participant explains this point more clearly:

Previously we were forced to talk but we were not confident enough to talk since we had no knowledge. In this class, however, things were different since we read to talk and write. Therefore, we have broad information related to the topic we are required to write and speak, therefore, we were confident and motivated since we had something to talk about. Most of the time, in traditional classes we preferred not to talk because we did not have any information about that subject.

\subsection{Saving Class Time}

When teacher breaks the language into skills and components and focuses on one skill or component at a time, teachers do not have sufficient time to cover them all. On the other hand, when skills are presented in an integrated fashion, there is sufficient time for practice and communication. Previously, the researchers' main concern was coverage of the textbook, with this approach, however, their concern has shifted away from coverage towards communication. One of the participats substantiates this point by saying:

Previously the teacher focused on one skill at a time. So he didn't have time to practice all the skills. Here we read a text, get some ideas and use those ideas for speaking and writing. So there is enough time to cover all the skills and sub-skills. I think, this method provides enough time and chance for me to practice speaking skill and by talking about the reading topics and discuss with other students and at the same time learn new words and structures. Compared with other methods, in one session we cover all the skills. In the past we focused exclusively on grammar, vocabulary or one language skill. Since we didn't have enough time, the teacher tried to finish the book

Previously teachers had to analyze the reading passage, explain the new language items such as vocabulary and grammar help the students do lots of mechanical exercises. Teachers always complained that they do not have sufficient time. With the ISA, however, the teacher encourages the students to read the text as quickly as they, get some ideas, and then use them in speaking and writing. One of the participants explains this strength as follows:

Before I entered this class, I thought we read to learn grammar and vocabulary because we analyzed the text to learn grammar and it took a long time to learn the meaning of new words. In this class, however, the teacher does not force us to learn the meaning of all new words. Instead, the teacher told us to read the text quickly, get some ideas for speaking and writing in a very short time. So we are not worried about time since we are not supposed to get all the details of the text.

\subsection{Reduction in Learners' Stress}

The integrated approach focuses on meaning rather than form; communication rather than language; fluency rather than accuracy; reading for information rather than mastery of language forms. Thus compared with other methods, it is stress-free. One of the participants explains:

When we read the texts, we are not required to read all the details to answer questions at the end of the texts. Rather, we are required to read, get some ideas and use them when communicating with our friends. Since we focus on the parts we understand, we are not stressed. Moreover there is no stress since there is no right or wrong answers. Different students read the same text but get different things and then communicate their ideas with their friends. Through the process of communication we learn from each other and deepen our understanding the text.

This approach is cognitively less demanding and consequently less stressful since it focuses on getting and 
exchanging ideas rather than memorizing useless facts about language. Moreover speaking is less stressful since the reading gives the learners some ideas to exchange. One of the participants contends:

In the other classes teachers specified a topic and forced us to talk. Since we had no or limited knowledge of the topic, speaking was very demanding and stressful while in this approach speaking is fun and stress-free since the reading passage gives us a lot of ideas to exchange. Similarly, writing is fun since the reading passage gives us lots of knowledge. Previously, writing was very stressful since we thought and thought and we could not remember any relevant information about the subject but now we write to restate the ideas we got fro the text in our own words.

Since students communicate to exchange views about the text, they have a friendly relationship with each other and this reduces their level of stress. One of the participants explains:

In the other terms, the teacher wanted us to read the texts and answer the questions. This was stressful because the teacher always negatively judged our performance and because we had to work individually. Here we work in pairs and the teacher is not there to judge our performance. Learning from peers is fun while waiting for teachers' judgment is very stressful.

\subsection{Provision of Reflection Time}

An integrated approach allows learners to explore, gather, process, refine and present information about topics they want to investigate without the constraints imposed by traditional subject barriers (Pigdon and Woolley, 1992). Learners are given the chance to interact in an authentic and meaningful way and are exposed to the richness and complexity of the language. During speaking students have very little time at their disposal to reflect upon what they say. To fill in this gap, in the integrated approach are asked to read the text, get some ideas, reflect on the ideas by relating them to their own knowledge and experience and then exchange them with their friends. Participants really welcomed this reflection time after reading. One of them says:

We read the text to get some ideas for reading and writing. However, before we started speaking or writing, the teacher wanted us to reflect on the ideas we received from the text by relating them to our previous knowledge and experience and then exchange them. I really liked this reflection time because in other classes we memorized the content of the text but here we got the ideas from the text but rather than report them, we evaluated them by agreeing or disagreeing with the writer. This was all because of reflection time after reading the texts.

In addition to the reflection period provided after reading, we were asked to reflect on what was exchanged during pair work. One of the participants explains:

Our teacher told us to reflect upon what your partners' understanding of the text. Instead of passively listening to my partner, the teacher told us to reflect on what we hear and agree or disagree. I really liked this process since I had to think a lot to disagree with what my friend said.

\subsection{Reconceptualization of Teacher's Role}

This approach is conducive to a learner-centered approach since students have an active part in constructing and meaning during reading, writing and conversational exchange with the partners. In the traditional approaches teacher's role is central since he is the only active participants and students are the passive receiver of information transmitted by the teacher. Thus this approach reconceptualizes teachers' role as a facilitator who guides and design opportunities cooperation among learners (Pollard, 2001). One of the participants better explains the new identity language teachers take:

Before entering this class, I wrongly believed that teachers should actively teach the lesson and we should just listen. In this class, however, I saw that each and every student is as active as the teacher. Here the teacher gave us some background knowledge so that we can read the text more effectively, invited us to read the text, get ideas and reflect on them. So it was the students who read the text and did the reflection. During writing or conversation, he observed our performance and helped us to communicate what we could not on our own.

Another participant also noticed the change in teachers' role and expressed her satisfaction with this new role by saying:

I believe the class is really boring when the teacher is the only speaker in the classroom. And it is really fun when you see that all students are actively involved in exchanging the points they took from the text. Previously I thought we should wait for the teacher to give us the right answer. Here however, I found that students themselves can get some ideas from the texts although there was no prior teaching. When I read the text and expressed what I got, it was really amazing when the teacher approved of what I said or what my partner said.

Research has shown that students' perceptions of the teachers' behavior are strongly linked to their achievement 
and motivation in all subjects. Since the teacher minimizes teaching time, he maximizes the opportunity for learning and students take over the responsibility and mover towards learner autonomy.

\section{Summary and Discussion}

The study aimed at exploring learners' perceptions of the ISA. The results clearly show that learners entheusiastically accept this approach to teaching English as a foreign language since among other things it:

- Increases learners' motivation and self-confidence by presenting something worthwhile to talk about;

- Reduces their level of stress and axeity by engaging them in real communication of ideas rather than mechanical practice of skills and components;

- Shifts teachers' attention away from coverage of the textbook towards involving students in communication since integration saves time;

- Encourages simultaneous use of all the language skills and creates conditions that are conducive to real communication as opposed to contived practice of isolated skills;

- Provides the learners with reflection time. This is something which is missing in the communicative approach to teaching since it focuses on spontaneous language use and penalizes reflective learners; and

- Reconceptualizes teachrs' role, i.e., it is conducive to a learner-centered approach since students have an active part in constructing and meaning during reading, writing and conversational exchange with the partners.

Taking the foregoing findings into account the study has clear implications and applications since the findings: (1) shed some lights on the unitary competence hypothesis and presents significant evidence against the divisibility hypothesis which dominates researchers' and practitioners' thoughts; (2) encourages practitioners to shift awy from skills and components approach towards integrating skills.

\section{References}

Brown, H. D. (2001). Teaching by principles: An interactive approach to language pedagogy (2nd ed.). White Plains, NY: Addison Wesley Longman.

Canale, M., \& Swain, M. (1980). Theoretical bases of communicative approaches to second language teaching and testing. Applied Linguistics, 1, 1-47.

Charmaz, K. (2003). Grounded theory. In M. Lewis-Beck, A. Bryman, \& T. F. Liao (Eds.), The sage encyclopedia of social science research methods (pp. 440-444). London: Sage.

Corder, S. P. (1971). Idiosyncratic dialects and error analysis. IRAL, 9(2), 147-160.

Corder, S. P. (1978). Language-learner language. In J. C. Richards (Ed.), Understanding second and foreign language learning (pp. 71-92). Rowley, MA: Newbury House.

Dabbaghi, A. (2006). A comparison of the effects of implicit/explicit and immediate/delayed corrective feedback on learners' performance in tailor-made tests (Unpublished Ph.D. Dissertation). The University of Auckland.

Enright, D. S., \& McCloskey, M. L. (1988). Integrating English: Developing English language and literacy in the multilingual classroom. Boston: Addison-Wesley.

Faltis, C. J. (1993). Join fostering: Adapting teaching strategies for the multilingual classroom. New York: Merrill/Macmillan.

Fulton-Scott, M. J., \& Calvin, A. D. (1983). Bilingual multicultural education vs. integrated and nonintegrated ESL instruction. NABE Journal, 7(3), 1-12.

Glaser, B. G., \& Strauss, A. L. (1967). The Discovery of Grounded Theory: Strategies for Qualitative Research. Chicago: Aldine Publishing Company.

Hinkel, E. (2010). Integrating the four skills: Current and historical perspectives. In R. B. Kaplan (Ed.), Oxford Handbook in Applied Linguistics (pp. 110-126). Oxford: Oxford University Press.

Hymes, D. (1972). On communicative competence. In J. Pride, \& J. Holmes (Eds.), Sociolinguistics: Selected readings. Harmondsworth, England: Penguin Books.

Jing, W. (2006). Integrating Skills for Teaching EFL—Activity Design for the Communicative Classroom. Sino-US English Teaching, 3(12), 122-133. http://www.linguist.org.cn/doc/su200612/su20061201.pdf 
Joglekar, S., Bhuiyan, P. S., \& Kishore, S. (1994). Integrated teaching—our experience. Journal of Postgraduate Medicine, 40(4), 231-232.

Kaplan, R. (1970). The mind system: A grammar-rule language. Santa Monica, California: The RAND Corporation.

Kumaravadivelu, B. (2003). Beyond methods: Macrostrategies for language teaching. New Haven, CT: Yale University Press.

Kvale, S. (1996). InterViews - An introduction to qualitative research interviewing. Thousand Oaks, CA: Sage.

Martin, P. Y., \& Turner, B. A. (1986). Grounded theory and organizational research. The Journal of Applied Behavioral Science, 22(2), 141-157.

Mmela, E. (2006). Implementing Integrated Literacy Approaches in an English Classroom in Malawi (Doctoral dissertation). Virginia Polytechnic Institute and State University.

Myers, J. W., \& Hilliard, R. D. (1997). Holistic language learning at the middle level: Our last, best chance. Childhood Education, 73, 286-289.

Ostovar-Namaghi, A. (2011). Teaching as a Disciplined Act: A Grounded Theory. Journal of Language Teaching and Research, 2(4), 837-843.

Oxford, R. (2001). Integrated skills in the ESL/EFL classroom. ERIC Digest. Retrieved May 15, 2002, from http://www/cal.org/ericcll/0105oxford.html

Pigdon, K., \& Woolley, M. (1992). The Big Picture. Victoria: Eleanor Curtain Publishing.

Pollard, A. (2001). Reflective teaching in the primary school. New York: Continuum.

Richard-Amato, P. A. (1996). Making It Happen. New York: Addison-Wesley.

Richards, J. C., Platt, J., \& Weber, H. (1988). Longman dictionary of applied linguistics. Harlow: Longman.

Richards, J. C., \& Rodgers, T. (2000). Approaches and methods in language teaching: A descriptive analysis. Cambridge: Cambridge University Press.

Roberts, L., \& Kellough, D. (2000). A guide for developing interdisciplinary thematic units (2th ed.). Columbus, Ohio: Merrill.

Savignon, S. (1983). Communicative competence: Theory and classroom practice. Reading, MA: Addison-Wesley.

Savignon, S. (1990). Communicative language teaching: Definitions and directions. In J. E. Alatis (Ed.), Georgetown University Round Table on Languages and Linguistics, 1990. Washington, DC: Georgetown University Press.

Schön, D. A. (Ed.). (1993). The reflective turn: Case studies in and on educational practice. New York: Teachers College Press.

Schurr, S., Thomason, J., \& Thompson, M. (1995). Teaching at the middle level: A professional's handbook. Lexington, MA: D. C. Heath.

Strang, R. (1972). Developing oral expression. In H. D. Funk, \& D. Triplett (Eds.), Language Arts in the Elementary School: Readings (pp. 287-293). Philadelphia: J. P. Lippincott Company.

Stern, H. H. (1992). Issues and Options in Language Teaching. Oxford: Oxford University Press.

Widdowson, H. G. (1978). Teactiing Language as Communication. Oxford: Oxford University Press.

Wubbels, T., Brekelmans, M., den Brok, P., \& van Tartwijk, J. (2006). An interpersonal perspective on classroom man-agement in secondary classrooms in the Netherlands. In C. Evertson, \& C. Weinstein (Eds.), Handbook of classroom management: Research, practice, and contemporary issues (pp. 1161-1191). Mahwah, NJ: Lawrence Erlbaum Associates.

\section{Copyrights}

Copyright for this article is retained by the author(s), with first publication rights granted to the journal.

This is an open-access article distributed under the terms and conditions of the Creative Commons Attribution license (http://creativecommons.org/licenses/by/3.0/). 